\title{
ФУНКЦІЇ ПІДРУЧНИКА УКРАЇНСЬКОЇ МОВИ В КОМПЕТЕНТНІСНІЙ ПАРАДИГМІ
}

\author{
ОЛЕНА ГОРОШКІНА \\ Інститут педагогіки НАПН України, Київ - Україна \\ olenagoroshkina@gmail.com; ORCID: 0000-0002-0378-888X \\ FUNKCJE PODRĘCZNIKA DO JĘZYKA UKRAIŃSKIEGO \\ W PARADYGMACIE KOMPETENCYJNYM \\ OLENA HOROSZKINA \\ Instytut Pedagogiki NANP Ukrainy, Kijów - Ukraina
}

\begin{abstract}
STRESZCZENIE. W artykule określono funkcje podręcznika do języka ukraińskiego, zwłaszcza światopoglądową, wartościująco-orientacyjną, rozwijającą, informacyjną, refleksyjno-korekcyjną. Szczególną uwagę zwrócono na kwestię wprowadzenia podejścia kompetencyjnego do procesu kształcenia, co warunkuje przekształcenie funkcji podręcznika, wyodrębnienie nowych funkcji, które odpowiadają współczesnym wyzwaniom społecznym.

Słowa kluczowe: język ukraiński, funkcje podręcznika, podejście kompetencyjne, transformacja, wyzwanie społeczne.

\section{FUNCTIONS OF THE UKRAINIAN LANGUAGE TEXTBOOK IN COMPETENCE PARADIGM}

\author{
OLENA HOROSHKINA \\ Institute of Pedagogics NAPS of Ukraine, Kyiv - Ukraine
}

\begin{abstract}
The article outlines the functions of the Ukrainian language textbook, in particular world outlook function, developing, informative, reflective, corrective functions. Particular attention is paid to the problem of a competence approach implementation in the educational process, which causes the textbook functions transformation, singling out of new functions, which correspond to the new social challenges.

Key words: the Ukrainian language, textbook functions, competence approach, transformation, social challenge.
\end{abstract}

2 поміж низки проблем, що стоять перед сучасною національною освітою, $\epsilon$ такі, без розв'язання яких не будуть працювати ані жодна концепція навчання, ані жодна освітня технологія. До таких належить проблема розроблення шкільних підручників нового типу — за змістом, функціями, способами викладу навчального матеріалу.

Вивчення спеціальної літератури переконує, що проблемі створення сучасного підручника української мови присвячено студії Н. Бондаренко, Н. Голуб, С. Карамана, Л. Мацько, Г. Михайловської, М. Пентилюк, Л. Скуратівського, В. Тихоші, Г. Шелехової, А. Ярмолюк та ін. Науковцями визначено функції, принципи побудови підручників (Н. Бондаренко, К. Плиско, Л. Рожило, А. Ярмолюк та ін.), критерії відбору навчального матеріалу (О. Біляєв, Л. Мацько, М. Пентилюк та ін.), соціокультурний потенціал (О. Горошкіна, В. Дороз, Д. Кобцев, М. Пентилюк, Л. Попова, В. Шляхова, А. Ярмолюк). С. Караман 
i В. Тихоша слушно зазначають: „Підручник - один із найскладніших жанрів навчальної літератури. Складність полягає в тому, що перед авторами стоїть багатоаспектна мета, для здійснення якої потрібно врахувати й пов'язувати в єдине ціле безліч різнорідних вимог - мовних, методичних, соціальних, психологічних, українознавчих тощо"1. Висловлена авторами статті думка досі не втрачає своєї актуальності, оскільки й нині нерозв'язаним залишається питання про створення підручника української мови, що відповідав би потребам компетентнісного підходу.

Мета статті - окреслити функції підручників української мови в компетентнісному вимірі, визначити дидактико-розвивальний потенціал підручника у формуванні ключових і предметної компетентностей учнів.

У сучасному освітньому просторі відбувається становлення компетентнісного підходу, що задекларовано в низці стратегічних документів. Теорію компетентнісного підходу досліджували зарубіжні (Д. Мертенс, Б. Оскарсон, Дж. Равен, А. Шелтен та ін.) й українські (І. Бех, Н. Бібік, О. Локшина, О. Овчарук, О. Пометун, О. Савченко, О. Топузов та ін.) вчені. Оскільки ця теорія сьогодні ще в стадії становлення, то цілком природньою $є$ наявність кількох її визначень. У Державному стандарті базової і повної загальної середньої освіти компетентнісний підхід потлумачено як спрямованість навчально-виховного процесу на досягнення результатів, якими є ієрархічно підпорядковані ключова, загальнопредметна і предметна (галузева) компетентності²; у такому ж контексті визначають підхід українські науковці О. Савченко, О. Пометун: спрямованість навчально-виховного процесу на формування й розвиток ключових (базових) і предметних компетентностей ${ }^{3}$; спрямованість освітнього процесу на формування та розвиток ключових (базових, основних) і предметних компетентностей особистості (О. Пометун). Одностайність у тлумаченні поняття “компетентнісний підхід“ свідчить про те, що його визначають як провідний вектор підвищення якості освіти, О. Пометун конкретизує визначення, зазначаючи, що „результатом такого процесу буде формування загальної компетентності людини, що $є$ сукупністю ключових компетентностей, інтегрованою характеристикою особистості. Така характеристика має сформуватися в процесі навчання й містити знання, уміння, ставлення, досвід діяльності й поведінкові моделі особистості" (жирн. шрифт автор. - О. Г.) ${ }^{4}$.

Аналіз і синтез наукових студій засвідчує, що компетентнісний підхід визначають як методологію модернізації системи освіти; провідний напрям підвищення якості освіти. Індекс активності обговорення феномену компетентності, компетентнісного підходу на наукових конференціях, форумах високий, значну кількість дисертаційних праць теж присвячено розв'язанню порушеної проблеми, науковцями запропоновано багато визначень ключового поняття,

${ }^{1}$ С. Караман, В. Тихоша, Технологія створення підручників і посібників для поглибленого вивчення української мови в гімназї̈, [в:] „Дивослово”, 2001, № 4, с. 36.

2 Державний стандарт базової і повної загальної середньої освіти: Постанова Кабінету Міністрів України № 1392 від 23 листопада 2011 року, [в:] Електронний ресурс: http://school164. klasna.com/uk/site/novii-derzhavnii-standart.html.

${ }^{3}$ Контроль та оцінювання навчальних досягнень учнів початкової школи, метод. рек., кол. авт.: Н. М. Бібік (кер.), О. Я. Савченко, Т. М. Байбара, М. С. Вашуленко та ін., Київ 2002.

${ }^{4}$ О. І. Пометун, Теорія та практика послідовної реалізації компетентнісного підходу в досвіді зарубіжних краӥн, [в:] Компетентнісний підхід у сучасній освіті: світовий досвід та українські перспективи, бібліотека з освітньої політики, під заг. ред. О.В.Овчарук, Київ 2004, c. $15-24$. 
однак семантичне наповнення його донині немає чіткого змісту, а відтак обростає новими смислами. Опрацювання наукових праць уможливлює висновок: компетентність - це власний досвід суб'єкта навчання, здобутий у процесі навчання, самонавчання, саморозвитку під керівництвом учителя-словесника; предметні і ключові компетентності - це не сума знань, хоча знання мають винятково важливе значення, це не відомості з підручників, словників, інтернетних джерел, що розширюють межі програми, і навіть не вміння застосовувати ці знання; компетентність - це особлива особистісна якість, що є результатом саморозвитку учня за допомогою вмілого наставника - учителя, майстра своєї справи. На відміну від знаннєвого досвіду компетентність не можна передати в готовому вигляді, кожен учень самостійно формує власну компетентність.

Основне завдання компетентнісного підходу в освіті полягає в посиленні діяльнісно-особистісного аспекту в навчанні, забезпеченні набуття особистісного досвіду учнів. Упровадження компетентнісного підходу зумовлює зміни, що відбуваються на рівні змісту, організації освітнього процесу, особистісних характеристик його суб'єктів. Зміни на рівні змісту передбачають оновлення змісту навчання, що відповідав би викликам сьогодення; добір особистісно важливих для учнів завдань; збільшення питомої ваги завдань, які не мають однозначних правильних відповідей; застосування особистісно й соціально важливих комунікативно орієнтованих ситуацій, спрямованих на оволодіння конкретним практичним досвідом. Зміни на рівні організації освітнього процесу передбачають реалізацію індивідуальної освітньої траєкторії; домінування самостійної пізнавальної діяльності учнів; розширення освітнього простору (ефективне застосування інтернетних джерел в освітньому процесі); забезпечення можливостей для створення учнями власного освітнього проекту; розвиток пізнавальної, соціальної, індивідуальної і колективної рефлексії; розроблення персоналізованої системи оцінювання, що максимально враховує когнітивні можливості, мету кожного учня. На рівні особистісних характеристик зміни стосуються переважно стимулювання творчості, ініціативності, толерантності, емпатії учнів; розвитку критичного мислення шляхом формування вмінь аналізувати інформацію, робити самостійні висновки задля використання отриманих результатів у різних ситуаціях.

Переорієнтація на компетентнісний підхід забезпечує посилення прикладного характеру мовної освіти, що вможливлює використання теоретичних знань як практичного засобу пояснення явищ і розв'язання проблем, застосування досвіду успішних дій у конкретних ситуаціях, переорієнтацію з процесу на результат освіти в діяльнісному вимірі, що, відповідно, стає імпульсом для розроблення підручника української мови, що відповідав би високим соціальним очікуванням і став для учня особистісною програмою саморозвитку. Зміна ролі теоретичних знань зовсім не означає зниження їхнього рівня або спрощеного способу подачі в шкільному підручнику. Навпаки, увага до відповідних мовних засобів вираження одних і тих самих значень, до відтінків семантичного плану, обов'язкове використання набутих знань у конкретних ситуаціях спілкування роблять знання більш міцними, дієвими, а їхнє засвоєння мотивованим.

Дидакти визначають підручник як навчальну книгу, у якій викладені основи знань $з$ певного навчального предмета на рівні сучасних досягнень науки й культури відповідно до освітніх стандартів і програм ${ }^{5}$. На нашу думку, традиційне визначення потребує доповнення стосовно підручника української

\footnotetext{
${ }^{5}$ С. У.Гонч Гаренко, Украӥнський педагогічний словник, Київ 1997, с. 260.
} 
мови, що є важливим засобом самовдосконалення учня, формування його МКС. Як особливий жанр навчальної літератури підручник української мови — це теоретико-практичне видання, цілісна компетентнісно орієнтована система, побудована відповідно до загальнодидактичних принципів навчання, а також з урахуванням лінгводидактичних принципів, насамперед комунікативної спрямованості, діалогізації суб'єктів навчання, соціокультурної відповідності, що забезпечує реалізацію сучасних підходів до навчання української мови, передусім виокремлених у Державному стандарті базової і повної загальної середньої освіти - особистісно зорієнтованого, діяльнісного й компетентнісного.

Вивчення спеціальних джерел засвідчило, що підгрунтя для розроблення підручників української мови нового типу було закладено ще в 70-ті рр. $\mathrm{XX}$ століття провідними лінгводидактами - О. Біляєвим, М. Пентилюк, К. Плиско, Л. Симоненковою, М. Шкільником та ін., продовжено Н. Бондаренко, В. Новосьоловою, Л. Скуратівським, Я. Остаф, Г. Шелеховою, І. Ющуком, А. Ярмолюк та ін. Останнім часом активно розробляють проблему створення електронних підручників з української мови - навчальних програмних засобів нового покоління (В. Бадер, Н. Семенів, Г. Шелехова, Ю. Шепетко, Л. Шиліна, В. Шляхова, Т. Ясак та ін.). Як свідчить опрацювання літератури з проблеми цього дослідження, українське підручникотворення має потужні традиції. Сьогодні важливо зберегти напрацьовані різними авторськими колективами традиції наукової надійності, методичної адаптації теоретичного матеріалу, однак необхідно враховувати й те, що змінилися соціальні умови, а відтак і соціальне замовлення, змінився суб'єкт навчання - учень. Зазнають змін і підручники. Традиційно вважають, що підручник - основне джерело інформації, тренажер для закріплення отриманих у класі теоретичних відомостей, що й зумовило структуру підручників: спочатку стисло подано теоретичні відомості в текстовому варіанті або як таблиці, схеми, потім вправи, спрямовані на закріплення здобутих знань і вироблення в учнів визначених чинною програмою вмінь і навичок. В умовах сучасного соціокультурного контексту традиційні функції підручника розмиваються, натомість цей засіб набуває інших функцій, оскільки він має навчити учнів ,діяти за межами навчальних сюжетів і навчальних ситуацій” (В. Болотов) ${ }^{6}$.

Перед авторами підручників постають проблеми мотиваційного характеру. У цьому контексті варто максимально врахувати дослідження психологів щодо розвитку і стабільної підтримки пізнавального інтересу учнів до навчання. Для того, щоб забезпечити інтерес учнів до предмета, стимулювати їхню активність, необхідно закласти в підручник такий алгоритм роботи, щоб вони відчували, що в результаті навчання розвивається їхнє мовлення, розумові здібності, пам'ять, увага та інші психічні якості, тобто необхідна обов'язкова мотивація діяльності. На думку вчених (I. Зимня, С. Максименко, І. Синиця та ін.), інтереси підлітків, як правило, мають різнобічний і водночас вибірковий характер. Ïх приваблює все нове, що не пізнане й не пережите ними. Однак, якщо учень не бачить життєвої необхідності знань, не може використати власний життєвий досвід під час створення висловлювання, то в нього може сформуватися негативне ставлення до предмета.

Спробуємо уточнити функції сучасного підручника української мови. I. Підласий 3-поміж низки інших визначає три основні функції шкільного під-

${ }^{6}$ В. А. Болотов, В.В.Сериков, Компетентностная модель: от идеи к образовательной программе, [в:] „Педагогика”, 2003, № 10, с. 8-14. 
ручника - мотиваційну, що полягає в створенні таких стимулів для учнів, які спонукають до опанування предмета, формують інтерес і позитивне ставлення до навчання; інформаційну, що дає змогу учням розширювати обсяг знань; контрольно-корекційну, що передбачає можливість перевірки, сомооцінювання й корекції перебігу й результатів навчання, а також виконання тренувальних вправ для формування необхідних умінь і навичок?

К. Плиско виокремила такі функції шкільного підручника української мови: інформаційну (підручник $є$ провідним засобом опанування нового матеріалу, повторення вивченого раніше), систематизувальну (підручник репрезентує відомості з предмета у певній системі), трансформувальну (підручник оптимізує трансформацію знань учнів у стійкі вміння й навички), виховну (зміст підручника має значний виховний потенціал) функції ${ }^{8}$ Аналіз змісту сучасних підручників української мови, спостереження за освітнім процесом, студіювання спеціальної літератури вможливили виокремлення в контексті компетентнісного підходу низки нових функцій підручників, до яких відносимо світоглядну, ціннісно-орієнтувальну, комунікативну, розвивальну.

Одним з механізмів формування світогляду є освіта. Беремо до уваги думку I. Лернера, що світогляд особистості - це система максимально узагальнених наукових знань про дійсність, місце людини в ній, уміння цими знаннями користуватися задля пізнання й перетворення дійсності, переконаності в істинності й ефективності знань як інструмента діяльності основних ідеалів, принципів і готовності до реалізації й захисту переконань та ідеалів 9 . 3 огляду на це розглядаємо світоглядну функцію підручника як його спроможність формувати в учнів методологічні знання, МКС, залучення учнів до гуманістичних цінностей, розуміння мови як суспільного явища, унікального здобутку людства, усвідомлення всіх іiі функції, передовсім номінативної, гносеологічної, ідентифікаційної, естетичної. Реалізацію означених функцій здійснюють через систему відповідних вправ і завдань, спрямованих на вироблення в учнів умінь виражати власну позицію, не піддаватися нівелюванню власних мовленнєвих якостей, умінь позитивного й продуктивного спілкування тощо.

Важливим $\epsilon$ репрезентування мови в міжрівневих, внутрішньорівневих і міжпредметних зв'язках, що передбачає врахування того, що мова є складною багаторівневою системою, рівні якої містять набір певних мовних одиниць, тісно пов'язаних між собою. Урахування цих зв'язків під час вивчення української мови дасть учням змогу усвідомити мову як систему, що постійно розвивається, удосконалюється, збагачується, а також осмислити внутрішні закономірності кожного рівня мови.

Ціннісно-орієнтувальна функція підручника української мови набуває особливого значення, оскільки в сучасному суспільстві склалося протиріччя між необхідністю збереження національної культури, формування ціннісного ставлення до української мови й недостатньою розробленістю наукових підходів до формування цінностей в учнів. Підтримуємо наукову позицію Д. Карамишева в тому, що „актуалізація ціннісних вимірів набуває особливого значення в суспільстві, у якому знецінюються традиції та міжпоколінні зв'язки й іде-

${ }^{7}$ И. П. Подл асый, Педагогика: 100 вопросов - 100 ответов, учеб. пособие для студ. вузов, Москва 2006, с. 154.

${ }^{8}$ К. М. Плиско, Теорія і методика навчання украӥнської мови в середній школі, Харків 2001, c. 11 .

${ }^{9}$ Теоретические основы содержсания общего среднего образования, под ред. В. В. Краевского, И. Я. Лернера, Москва 1983, с. 71. 
ологічні настанови якого постійно підлягають деформації'10. Цей дослідник також зазначає: „...попри те, що переважна більшість населення віддає перевагу саме матеріальним цінностям, оскільки вони є системотворчими, у країні формується стійкий запит на цінності постматеріального й нематеріального характеру""11. У зв'язку з цим уважаємо доцільним включення до підручників вправ, пов'язаних зі спостереженням над усним і писемним мовленням на текстах, що мають значний ціннісно-розвивальний потенціал. Своєрідність сучасного підручника вбачаємо в пріоритетному використанні текстового навчального матеріалу, що репрезентує соціокультурні концепти, визначені в соціокультурній змістовій лінії програми, із поступовим розширенням їхнього інформаційного поля. Без соціокультурних відомостей вивчення української мови звужується до засвоєння фонетичних, лексичних і граматичних явищ. Важливо засобами вправ допомогти учням усвідомити мову й спілкування як цінність.

Одна 3 функцій підручника - інформаційна, оскільки за його допомогою учні опановують новий матеріал, повторюють вивчене раніше, проте останнім часом з'явилася низка довідників, посібників для учнів з української мови як на паперових, так і на електронних носіях, до того ж, учні застосовують широкі можливості інтернетних ресурсів. Нині можна говорити про втрату пріоритетності інформаційної функції підручника. Тому перед авторами навчальної книжки стоїть завдання: не просто подати учням готову інформацію, а запропонувати шляхи й підходи до оволодіння матеріалом. Можливості інформаційнокомунікаційних засобів значно ширші, ніж традиційного підручника: в інтернетній мережі учень може ознайомитися з відомостями, запропонованими в альтернативних підручниках, довідниках, статтях. Як видається, певну частину теоретичного матеріалу, оприлюдненого в інтернетній мережі на спеціальних освітніх ресурсах, доцільно подати в підручнику засобами QR-кодів, запропонувавши спеціальну графічну позначку — піктограму), натомість у підручнику подати більше особистісно важливих для учнів завдань, запропонувавши особистісно й соціально значущі комунікативно орієнтовані ситуації, спрямовані на оволодіння учнями конкретним практичним досвідом.

Як свідчать спостереження, на уроках української мови не повною мірою реалізується інформативний потенціал текстів, уміщених до підручників, та й сам добір текстового матеріалу в них подекуди здійснений безсистемно, хаотично. Відтак і вчителі, розв'язуючи комунікативні, розвивальні й виховні завдання на уроках мови, іноді послаблюють роботу над соціокультурною інформацією. Важливим складником сучасного підручника української мови мають стати відомості про традиції, побут, вірування українського народу, мовленнєвий етикет, інформація про відомих українців. Цікавим дидактичним матеріалом для учнів уважаємо образні крилаті вислови, у яких представлено спільний мовленнєвий досвід носіїв національної культури. Джерелом розвитку стійкого інтересу до навчання української мови може стати використання потенціалу міжпредметних зв'язків у навчанні, зокрема української мови з іноземною, українською та світовою літературою, історією, географією, образотворчим мистецтвом, музикою. Міжпредметні зв'язки виявляються й у використанні текстів відповідної тематики. 3 історією народу, його життям і побутом тісно пов'язані усна народна творчість, декоративно-ужиткове мистецтво. Робота

${ }^{10}$ Д. В. Карамишев, Формування системи иінностей і переконань як чинник інституизінальних перетворень в українському суспільстві, [в:] „Теорія та практика державного управління", 2016, № 1(52), с. 1-9.

${ }^{11}$ Д. В. Карамишев, зазнач. джер., с. 7. 
3 текстами різної жанрово-стильової належності інформаційно збагачує учнів і сприяє їхній адаптації до різноманітних комунікативних ситуацій.

Для вчителя текст - це засіб формування ціннісних орієнтацій, ключових і предметної компетентностей учнів; для школярів текст - джерело інформації, об'єкт розуміння й вивчення. Критеріями добору текстів уважаємо високий рівень їхньої інформативної насиченості, актуальність, доступність, що забезпечує можливість адекватного сприймання змісту твору синхронно 3 його читанням, наявність у тексті високого виховного потенціалу, наповненість дидактично значущими мовними одиницями відповідно до теми уроку, урахування психологічних особливостей реципієнтів - адресатів мовлення, досконалість відбору мовних одиниць у створенні тексту відповідного стилю й жанру мовлення, здатність тексту бути об'єктом пошукової діяльності учнів, спроможність тексту спонукати учнів до словесного самовдосконалення. Уважаємо, що пріоритет повинен віддаватися високохудожнім творам національного й світового, репрезентованого українською мовою, мистецтва. Системне використання текстового матеріалу ознайомлює учнів із характерними особливостями зв'язку висловлення й готує для глибокого розуміння класичних і створення власних текстів. Саме в процесі роботи з текстом розвивається емоційна сфера учнів, відбувається духовне збагачення. Важливими для методично правильної організації роботи з текстами є врахування сучасних досягнень психолінгвістики, когнітивної лінгвістики, стилістики, риторики, літературознавства, що різнопланово розглядають питання практичної реалізації мовної системи.

Сучасний підручник української мови має бути спрямованим на вироблення в учнів ефективних стратегій смислового читання й роботи 3 текстом, до яких належать стратегія пошуку інформації і розуміння прочитаного, стратегія перетворення й інтерпретування інформації, стратегія оцінювання інформаціï. Стратегія пошуку інформації і розуміння прочитаного передбачає такі кроки: визначення теми, головної думки, мети, призначення тексту; формулювання тези, що виражає загальний смисл тексту; смислове згортання інформації, висловленої в тексті; стратегія перетворення й інтерпретування інформації містить такі кроки, як структурування текстів з використанням списків, заголовків, покликань; перетворення текстового масиву в інші форми репрезентації інформації - таблиці, графіки, діаграми тощо, інтерпретування тексту, що передбачає зіставлення й протиставлення переданої в тексті інформації; стратегія оцінювання інформації передбачає вміння пов'язувати інформацію, уміщену в тексті, зі знаннями, наявними в учнів і отриманими з інших джерел. Означені стратегії доцільно максимально використовувати в підручниках для старших класів, однак у середніх класах вони можуть реалізуватися частково, передусім через уведення таких прийомів, як виділення ключових слів у тексті, маркування тексту (я знаю й розумію; я знаю, але не дуже розумію - ией матеріал є складним для мене, я не знаю - цей матеріал новий для мене), заповнення таблиць “Знаю — хочу дізнатися — дізнався (дізналася)", добір заголовка до тексту,

Зміст підручника доцільно спрямувати на зміщення акцентів 3 навчання мовної теорії на оволодіння мовою як даром рідного слова, вправляння в усному й писемному мовленні, спілкуванні, розвиток мовлення, створення максимально сприятливих умов для мовленнєвої самореалізації здібних і обдарованих учнів через упровадження в практику творчих вправ, дослідницькопошукових завдань, проведення мовних спостережень і дослідів, лінгвістичних ігор, розвиток монологічного й діалогічного мовлення тощо. Особливої значу- 
щості набуває проведення систематичної роботи з розвитку лінгвокреативності учнів, що зумовлює введення вправ і завдань, спрямованих на опанування прийомів мовленнєвої ефективності, формування в учнів уявлення й про граматичне значення слова, що є складним для їхнього сприймання абстрактним поняттям і традиційно викликає утруднення. У цьому допоможе мовна гра.

Спостереження переконують: для оживлення процесу спілкування підлітки вдаються до мовної гри, що свідчить про усвідомлене входження їх у простір неканонізованого спілкування. Лінгвістичні підвалини для формування новітнього напряму сучасної лінгводидактики - методики формування лінгвокреативності учнів засобами мовної гри закладають праці О. Важеніної, Н. Карпенко, Т. Космеди, Т. Осіпової, В. Санникова, Л. Ставицької, О. Халіман та ін. До підручника доцільно включати вправи, що ілюструють мовну гру, оскільки ігрове сприймання слова сприяє розвиткові мовленнєвої культури особистості, застосування мовних одиниць в ігровому контексті формує в учнів неусвідомлене розуміння мовної норми, лінгвокреативності.

Прикметною ознакою сучасного підручника з української мови $є$ спрямованість на формування ключових і предметної компетентностей учнів. Як зазначено в стратегічному документі "Нова українська школа", ключові (загальноосвітні) компетентності - це здатності, яких потребує кожен учень як суб'єкт освітнього процесу для самовизначення, загального розвитку й самореалізації. До ключових компетентностей віднесено: спілкування державною мовою (СДМ), уміння вчитися впродовж життя (УВВЖ), математичну компетентність (МК), компетентності у природничих науках і технологіях (КПНТ), інформаційно-комунікаційна компетентність (IКК), підприємницька компетентність (ПК), здоров'язбережувальна (З3К), сочіальна і громадянська компетентності (СГК), загальнокультурна (ЗКК).

Усі вправи й завдання, уміщені в книжці, мають бути спрямовані на формування в учнів ключових компетентностей, задекларованих у стратегічному документі “Нова українська школа". Водночас зауважимо, що вправи й завдання, спрямовані на формування ключових компетентностей учнів, можуть мати здебільшого інтегративний, комплексний характер, оскільки передбачають одночасне формування кількох компетентностей, межі яких до певної міри умовні.

Важливою функцією підручника української мови вважаємо розвивальну, що полягає насамперед у розвиткові критичного мислення учнів, їхніх творчих здібностей, мовного чуття й реалізується в доборі матеріалу, системі завдань, що поступово ускладнюються від репродуктивних до креативних.

Опанування української мови має забезпечити ефективне засвоєння інших навчальних предметів. Аналіз програм з інших шкільних предметів (української літератури, математики, географії, біології тощо) засвідчив, що вони потребують сформованого „уміння ясно, точно, грамотно викладати свої думки в усній і писемній формах". У пояснювальній записці до програм наголошено на використанні таких інтелектуальних операцій, як формулювання гіпотез, узагальнень, уміння дати дефініцію, описати спостереження, експеримент тощо, кожне з яких має мовний складник, тож від того, як учень знає мову, залежить, як він опанує й інші навчальні предмети. Спонукають учнів до діалогу завдання на зразок: станьте співавтором тексту, дописавщи його; співавтором підручника, запропонувавши власні вправи чи опорні конспекти тощо.

На сьогодні однією з актуальних проблем сучасної школи $є$ соціалізація учнів, адже вміння жити в суспільстві потребує спеціального навчання: добре 
орієнтуватися в динамічному світі, будувати відносини з людьми в межах цивілізованого діалогу, приймати самостійні рішення. Життя доводить, що допомогти учневі швидко ввійти в соціум, стати його органічною частиною може риторика, отже, підручники потребують вправ, які б допомогли вчителевісловеснику залучати учнів до соціалізації засобами риторики. Перед авторами підручників стоїть украй важливе завдання: допомогти у створенні на уроках української мови риторичного середовища, передусім за рахунок уведення комунікативно значущих риторичних відомостей, вправ, спрямованих на формування риторичних умінь і навичок учнів. Як видається, правомірним уміщення до підручника супровідних вправ, що поряд з іншим завданням (лексичним, граматичним тощо містять і риторичне завдання). Традиційні завдання (сnишіть текст, уставляючи пропущені літери й розділові знаки, підкресліть, виконайте розбір тощо) варто доповнити так, щоб перевести навчальну ситуацію в риторичну площину, підвищити інтерес до вивчення предмета, активізувати пізнавальну діяльність учнів. Задля формування стійких умінь і навичок учнів необхідно здійснювати активізацію мовних одиниць у вправах, наближених до природного дискурсу.

Рефлексійно-корекційна функція підручника реалізується за допомогою вправ і завдань, тестів для самоперевірки. Здебільшого автори в кінці кожного розділу пропонують комплексні завдання на текстовому матеріалі або тестові завдання, що допомагають повторити вивчений матеріал. Видається доцільним винести тести на QR-коди, що дасть змогу зменшити обсяг підручника, а учням відразу виконати тестові завдання й отримати правильні відповіді. Спонукають до рефлексії запитання, уміщені в кінці кожного параграфа, на кшталт: Що нового я дізналася (дізнався) сьогодні на урочі? Я навчилася (навчився).... Ці вміння потрібні мені для того, щуоб... . Головні результати моєї роботи у ... . Мені найкраше вдалося... . Мені не вдалося... . Чому?

Реалізація нових функцій підручника потребує розроблення нової структури, гнучкої й різноманітної; репрезентація теоретичних відомостей є складним комбінуванням пояснювально-ілюстративного, проблемного шляхів подачі навчальної інформації. Водночас зауважимо, що сьогодні потрібні електронні додатки до підручників, які складаються 3 довідників, словників, що надавали б змогу учням самостійно працювати над підвищенням рівня своїх знань, умінь і навичок як складника ключових і предметної компетентностей.

Висловлені міркування репрезентують роздуми автора про шляхи розв'язання важливої лінгводидактичної проблеми. Окреслені орієнтири потребують обговорення й уточнення. Перспективним у межах обраної теми є побудова цілісної моделі підручника з української мови, окреслення напрямів підготовки електронних додатків до підручників української мови.

\section{Список використаної літератури}

Болотов В. А., Сериков В. В., Компетентностная модель: от идеи к образовательной программе, [в:] „Педагогика”, 2003, № 10, с. 8-14.

Гончаренко С. У., Украӥнський педагогічний словник, Київ 1997.

Державний стандарт базової $і$ повної загальної середньої освіти: Постанова Кабінету Міністрів України № 1392 від 23 листопада 2011 року, [в:] Електронний ресурс: http://school164.klasna.com/uk/site/novii-derzhavnii-standart.html.

Караман С., Тихоша В., Технологія створення підручників і посібників для поглибленого вивчення української мови в гімназії, [в:] „Дивослово”, 2001, вип. 4, с. 36-38. 
Карамишев Д. В., Формування системи цінностей і переконань як чинник інституціональних перетворень в украӥнському суспільстві, [в:] „Теорія та практика державного управління", 2016, № 1(52), с. 1-9.

Контроль та очінювання навчальних досягнень учнів початкової школи, метод. рек., кол. авт.: Н. М. Бібік (кер.), О. Я. Савченко, Т. М. Байбара, М. С. Вашуленко та ін., Київ 2002.

Плиско К. М., Теорія і методика навчання украӥнської мови в середній школі, Харків 2001.

Подласый И. П., Педагогика: 100 вопросов - 100 ответов, учеб. пособие для студ. вузов, Москва 2006.

Пометун О. І., Теорія та практика послідовної реалізаиії компетентнісного підходу в досвіді зарубіжних країн, [в:] Компетентнісний підхід у сучасній освіті: світовий досвід та українські перспективи, бібліотека з освітньої політики, під заг. ред. О. В. Овчарук, Київ 2004, с. 15-24.

Теоретические основы содержания общего среднего образования, под ред. В. В. Краевского, И. Я. Лернера, Москва 1983.

\section{Spysok vykorystanoi literatury [References]}

Bolotov V. A., Serikov V. V., Kompetentnostnaya model: ot idei k obrazovatelnoj programme [Competence Model: from Idea to Educational Programme], [v:] „Pedagogika”, 2003, № 10, s. $8-14$.

Honcharenko S. U., Ukrainskyi pedahohichnyi slovnyk [Ukrainian Pedagogical Dictionary], Kyiv 1997.

Derzhavnyi standart bazovoi i povnoi zahalnoi serednoi osvity: Postanova Kabinetu Ministriv Ukrainy № 1392 vid 23 lystopada 2011 roku [State Standard of Basic and Complete Secondary Education: Act of Cabinet of Ministers № 1392,23.11. 2011], [v:] Elektronnyi resurs: http://school164.klasna.com/uk/site/novii-derzhavnii-standart.html.

Karaman S., Tykhosha V., Tekhnolohiia stvorennia pidruchnykiv i posibnykiv dlia pohlyblenoho vyvchennia ukrainskoi movy $v$ himnazii [Technology of Creation Textbooks and Manuals for Advanced Learning of Ukrainian in Gymnasium], [v:] „Dyvoslovo”, 2001, vyp. 4, s. 36-38.

Karamyshev D. V., Formuvannia systemy tsinnostei i perekonan yak chynnyk instytutsionalnykh peretvoren v ukrainskomu suspilstvi [Formation of Values System and Views as Factor of Institutional Transformations in Ukrainian Society] [v:] „Teoriia ta praktyka derzhavnoho upravlinnia", 2016, № 1(52), s. 1-9.

Kontrol ta otsiniuvannia navchalnykh dosiahnen uchniv pochatkovoi shkoly: metod. rek. [Control and Assessment of Educational Plans at Primary School: Methodological Recommendations], kol. avt.: N. M. Bibik (ker.), O. Ya. Savchenko, T. M. Baibara, M. S. Vashulenko ta in., Kyiv 2002.

Plysko K. M., Teoriia i metodyka navchannia ukrainskoi movy v serednii shkoli [Theory and Methodology of the Ukrainian Language Teaching at Secondary School], Kharkiv 2001.

Podlasyj I. P., Pedagogika: 100 voprosov - 100 otvetov [Pedagogy: 100 questions 100 answers], ucheb. posobie dlya stud. vuzov, Moskva 2006.

Pometun O. I., Teoriia ta praktyka poslidovnoi realizatsii kompetentnisnoho pidkhodu $v$ dosvidi zarubizhnykh krain [Theory and Practice of Gradual Realization of Competence-based Approach in Foreign Experience], [v:] Kompetentnisnyi pidkhid u suchasnii osviti: svitovyi dosvid ta ukrainski perspektyvy, biblioteka z osvitnoi polityky, pid zah. red. O. V. Ovcharuk, Kyiv 2004, s. 15-24.

Teoreticheskie osnovy soderzhaniya obshhego srednego obrazovaniya [Theoretical Fundamentals of General Secondary Education], pod red. V. V. Kraevskogo, I. Ya. Lernera, Moskva 1983. 